\title{
Economic analysis of externalities caused by an open dump site: A case study of Meethotamulla dump site Sri Lanka
}

\section{G.K. Udugama * and U.A.D.P.Gunawardena}

Department of Forestry and Environmental Science, University of Sri Jayewardenepura, Sri Lanka

\author{
*gkudugama@gmail.com
}

\begin{abstract}
Open dumps not only cause environmental degradation but also cause losses to the country's economy. Due to ignorance by many, it has become the most common method of disposal of Municipal Solid Waste (MSW) in the country. Meethotamulla dump site is one such open dump site located in Kolonnawa Municipality in Western Province of Sri Lanka. Until its collapse in April 2017, 850 metric tons of MSW was dumped daily and around 1000 households were directly affected around the dumpsite. The externalities of open dumping are not directly observed in the market, thus often underestimated. Hence, the main objective of the study was to estimate the total cost of major externalities caused by an open dumpsite.

A household survey was conducted using a pre-tested questionnaire among the surrounding community of the dump site. Stratified random sampling was adopted and households were selected from distances of $100 \mathrm{~m}, 200 \mathrm{~m}, 300 \mathrm{~m}, 500 \mathrm{~m}$ and $700 \mathrm{~m}$ along three directions. A total of 117 households were surveyed from May to August 2016.

Various externalities were assessed by using different valuation techniques and cumulative value of all estimates was taken as the lower bound value of total annual damage cost of Meethotamulla dumpsite. The total cost of health damages perceived by surrounding community was estimated as Rs.91.50 million by using Cost of illness method, Human capital approach and Contingent valuation method whereas the value for loss of life was estimated as Rs.102.9 million based on value of statistical life. Annual preventive expenditure used to mitigate externalities such as odor, dust, disturbance due to insects, mosquitoes and flies, floods were estimated as Rs.2.77 million. The estimated cost for foregone benefit of clean groundwater based on the opportunity cost method was estimated as Rs.0.22 million per annum while loss of productive time on additional cleaning was estimated as Rs.7.37 million. Use of hedonic price method revealed that the annual loss of esthetic value due to the dumpsite was Rs.37.56 million. The study further revealed that dumpsite emits 24,632 tons of methane per year causing not only global warming but also an opportunity cost of carbon credits worth of Rs.928.18 million. The annual cost of all the externalities was estimated as Rs. 1,115.74 million with a per ton cost of Rs.3,596. Most of the time policy decisions on waste management are based on monetary values of costs and benefits which are directly observable in the market. However most of the costs are hidden thus they are underestimated, causing huge private and social costs to the country's economy. In order to make correct policy decisions related to municipal solid waste management, a proper identification, understanding and estimation of such externalities related to disposal of solid waste is a must.
\end{abstract}

Keywords: Open dump site, Externalities, Damage estimation 